\title{
MAPPING THE CRITICAL HABITATS FOR MIGRATORY SPECIES OF THE UPPER GRANDE RIVER REGION, MINAS GERAIS STATE, BRAZIL
}

\author{
SUZUKI, F.M. ${ }^{1}-$ ZAMBALDI, L.P.* - POMPEU, P.S.* \\ ${ }^{1}$ Universidade Federal de Lavras \\ University Campus, P.O Box-3037, CEP. 37200-000, Lavras, MG, Brazil \\ (phone: +55-35-3829-1200; e-mail:fm.suzuki@hotmail.com) \\ *Corresponding author \\ e-mail: ludzambaldi@hotmail.com,pompeu@dbi.ufla.br \\ (Received $18^{\text {th }}$ February 2013; accepted $5^{\text {th }}$ September 2013)
}

\begin{abstract}
Spawning sites, floodplain lakes and the vegetation integrity were mapped and quantified in the upper Grande River basin, to aid the conservation of local migratory fish fauna, including the management of the existing fish pass. The distribution of critical habitats for the life cycle of migratory species, such as spawning sites and nursery areas, is essential because some significant impacts, such as "source-sink" dynamics and ecological traps may take place depending on their distribution. We assessed seven lotic stretches throughout the upper Grande River basin, including the Aiuruoca, Capivari, Mortes, and Cervo tributaries and three regions in main stem. Floodplain lakes were present and well distributed in all of the tributaries and stretches of the Grande River, although all of them had less than half of the original vegetation. Due to their high density of eggs and larvae, the Mortes and Aiuruoca tributaries stood out as essential for fish recruitment in the basin. It was possible to figure out the current situation of the upper Grande River basin in terms of the remaining vegetation surrounding the lotic stretches, the presence of nurseries (floodplain lakes), and spawning sites (egg and larvae drift), and to propose management strategies for the entire basin.
\end{abstract}

Keywords: Conservation, ichthyoplankton, neotropical fish, nursery areas

\section{Introduction}

The acceleration of Brazilian economic development over the last decades has proportioned to a rising demand for electric energy, mostly from the use of hydropower source (Aneel, 2011). Although is important to economy growth, the river impoundments to production of electric energy represent one of main impacts for aquatic biodiversity, mainly for the fishes. For the migratory species, the dams represent insurmountable obstacle, both to upstream movement of adult as the downstream movement of their offspring toward to development areas.

Migratory fish represent only a small fraction of all neotropical ichthyofauna (Petrere, 1985; Godinho and Godinho, 1994; Agostinho et al., 2003). However, due to their size (Agostinho et al., 2003; Agostinho et al., 2007a) and greater abundance (Northcote, 1978), they are most appreciated by professional (Goulding, 1979; Godinho, 1993; Agostinho et al., 2003) and recreational fisheries (Agostinho et al., 2003).

The construction of fish passes has been one of the strategies adopted by Brazilian authorities and the energy sector to diminish the effects of these barriers on migratory fish communities. However, most facilities have been considered ineffective because the presence of critical habitats such breeding sites and nurseries (floodplain lakes) below and above the pass, plus the feasibility of downstream movements of eggs, larvae 
and adults through the reservoir and past the dam, are determinant for assessing whether a fish pass is working as a conservation tool (Pompeu et al., 2011).

The distribution of critical habitats is also essential because some significant impacts related to fish passes, such as "source-sink" dynamics (Godinho and Kynard, 2009) and ecological traps (Pelicice and Agostinho, 2008), may take place depending on their distribution. Because the number of dams is rising in Brazil, there is an increased risk of migratory species being confined to short river stretches without spawning sites or floodplains.

Studies on the drift of eggs and larvae (Nakatani et al., 1997a; 1997b; 2001; Baumgartner et al., 2004) highlight the importance of studying the ichthyoplankton to identify spawning sites and breeding grounds, which are essential areas for fish species recruitment. In contrast, remote sensing techniques combined with geographic information system tools can be applied to assess the occurrence of floodplain lakes and the integrity of the riparian vegetation (Meaille and Wald, 1990; Weng, 2002). The use of these data is relevant to identification of the areas or remaining stretch of rivers essential to conservation of fish species. The identification of these important areas that can be subsidize protection measures and management actions to preservation of fishes (Nakatani et al., 2001). Applying these tools in the Grande River basin is essential due to its enormous hydroelectric potential. Along the upper course there are four power plants: Furnas, Funil, Itutinga, and Camargos, in addition to numerous others planned for construction. The presence of these dams may be a critical factor in the success of fish recruitment in this basin. The reservoirs act as obstacles to ichthyoplankton from the lotic remnants of the basin (Suzuki et al., 2011). Among the hydroelectric dams mentioned, only the Funil Dam incorporates a fish passage mechanism (fish lift) in which many fish are transported upstream during the spawning season (Suzuki et al., 2011).

This study aimed to assess the distribution of critical habitats (spawning sites and floodplain lakes) and integrity of the vegetation within the floodplain of the upper Grande River basin, to aid the conservation of local migratory fauna, including the management of the existing fish pass.

\section{Material and methods}

\section{Study area}

The Grande River basin, which belongs to the upper Paraná River basin, covers an area of $143,000 \mathrm{~km}^{2}$, including $86,500 \mathrm{~km}^{2}$ within the State of Minas Gerais, Brazil. The Grande River originates from the Serra da Mantiqueira and travels 1,300 km until its confluence with the Paranaíba River (Cemig and Cetec, 2000). In the upper Grande River region, the Funil, Itutinga, and Camargos hydroelectric dams are located upstream of the Furnas reservoir. The following important tributaries have mouths located in the influence areas of these reservoirs: the Aiuruoca, the Capivari River, and the Mortes River, ordered from upstream to downstream. The Aiuruoca River, which drains directly into the Camargos reservoir, is located on the left margin of the Grande River. The Capivari and Mortes, located on the left and right margins, respectively, directly meet the Grande River at the Funil reservoir (Table 1). 
Table 1. Technical data for the Funil, Itutinga and Camargos hydroelectric power plants located along the upper Grande River, Minas Gerais, Brazil (http://www.cemig.com.br)

\begin{tabular}{c|c|c|c}
\hline \multirow{2}{*}{ Technical data } & \multicolumn{3}{|c}{ Hydroelectric dam } \\
\cline { 2 - 4 } & Funil & Itutinga & Camargos \\
\hline Number and type of turbines & 3 (Kaplan) & 4 (Kaplan) & 2 (Kaplan) \\
Fish pass & Lift & - & - \\
Type of reservoir & Run-of-the- & Run-of-the- & Pumped-storage \\
Maximum inundation area $\left(\mathrm{km}^{2}\right)$ & river & river & 73.35 \\
Installed power $(\mathrm{MWh})$ & 38.32 & 1.73 & 48 \\
Maximum reservoir volume $\left(\mathrm{hm}^{3}\right)$ & 180 & 52 & 792 \\
\hline
\end{tabular}

In the present study, we assessed seven lotic stretches throughout the upper Grande River basin. These included the Aiuruoca, Capivari, Mortes, and Cervo tributaries in addition to three stretches of the Grande River: between the Furnas reservoir and Funil dam (Furnas-Funil), between the Funil reservoir and Itutinga dam (Funil-Itutinga), and upstream of the Camargos reservoir (Fig. 1). Itutinga dam strongly regulate the river flow, while the Funil is considered a run of river Dam.

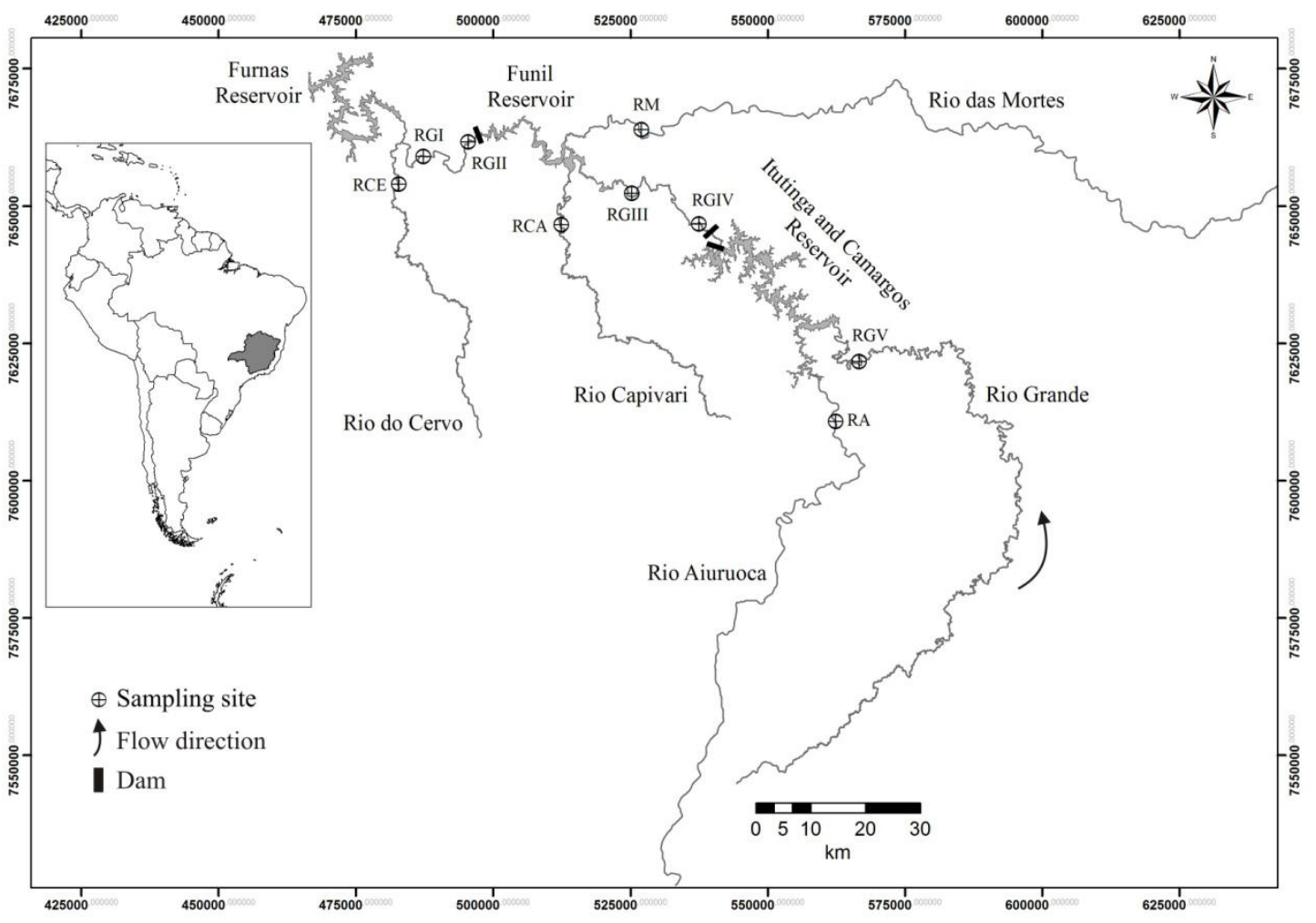

Figure 1. Locations of sampling site in the upper Grande River basin upstream of the Furnas Reservoir (Minas Gerais State, Brazil). $(R C E=$ Cervo River, $R M=$ Mortes River, $R C A=$ Capivari River, $R A=$ Aiuruoca River, $R G I=$ between Furnas and Funil, RGII=immediately downstream of the Funil Dam, RGIII=between Funil and Itutinga, RGIV=immediately downstream of the Itutinga Dam and RGV=upstream of the Camargos Reservoir) 


\section{Integrity of the riparian vegetation and quantification of floodplain lakes}

In the seven study areas, we quantified and mapped the natural vegetation and floodplain lakes considering a $1,000 \mathrm{~m}$ buffer from the river margins. Data were collected from the image classifications from the Landsat $5 \mathrm{TM}$ sensor satellite in the UTM coordinate system and WGS84 ellipsoid model. Areas covered by clouds were detected by reflectance values in the blue band and deleted from the images (Sakamoto, 2007). We classified the images using a multispectral pixel by pixel analysis, applying the maximum likelihood classification method. The training samples necessary for applying the method were obtained by collecting the coordinates from the area of interest in October 2008. The classification resulted in a map with three classes of interest: water (representing river courses and floodplain lakes), vegetation, and others.

The identification of floodplain lakes was determined through an object-oriented classification from a Landsat 5TM image taken on October 14th, 2008, using band 5 corresponding with the mid-infrared band with spatial resolution of $30 \mathrm{~m}$. The image for the analysis was chosen in the dry season because each river stretch experiences different flooding regimes during the rainy season. The images were segmented using 60 scales, which resulted in segments representing objects that were candidates for classification as floodplain lakes.

Polygons with spatial and spectral attributes (Table 2) similar to lakes were identified as floodplain lakes using the coordinates collected in the field. Polygons that did not represent floodplain lakes due to their location and context were manually deleted from the final classification.

Table 2. Gray levels values for attributes used in object oriented classification of floodplain lakes

\begin{tabular}{c|c|c|c}
\hline & Attributes & Minimum & Maximum \\
\hline \multirow{3}{*}{ Spectral } & Minimum values for band 5 & -0.0055 & 30.4000 \\
& Maximum values for band 5 & 0.0002 & 83.0078 \\
& Medium values for band 5 & -0.0007 & 55.4431 \\
\hline \multirow{5}{*}{ Spatial } & Area & 812.2500 & 2920642.7500 \\
& Size & 114.0000 & 8387.0137 \\
& Compact & 0.1866 & 0.2976 \\
& Convexity & 1.0000 & 1.3502 \\
& Solidity & 0.5384 & 1.0000 \\
& Form Factor & 0.2030 & 0.7923 \\
& Elongation & 1.0000 & 5.5583 \\
& Length of the longest axis of polygon & 38.0936 & 1119.2124 \\
& Length of the minor axis of polygon & 28.5000 & 730.2086 \\
& The ratio of the total area of the polygon to the & 0.9984 & 1.0000 \\
\hline
\end{tabular}

The classification accuracy was estimated using two statistical techniques: overall accuracy and Kappa accuracy. The first technique is a simple descriptive statistical method that calculates accuracy by dividing the correct total by the total number of pixels in the error matrix, while Kappa accuracy is a discrete multivariate technique containing a KHAT statistic. The accuracy values for classifying rivers and vegetation were $97.39 \%$ using the overall accuracy index and 96\% using the Kappa index. In 
classifying the floodplain lakes, the accuracy was estimated to be $90.25 \%$ using the overall accuracy index and $88 \%$ using the Kappa index.

\section{Ichthyoplankton sampling}

In order to assess the contribution of eggs and larvae from each tributary and each stretch of the Grande River, nine ichthyoplankton sampling points were defined downstream of each region (Fig. 1).

Samples were taken every two weeks from November 2008 to March 2009 twice per sampling day from 6 am to 9 am and $7 \mathrm{pm}$ to $9 \mathrm{pm}$. The samples were collected weekly only for the sampling point immediately downstream of the Funil dam. The samples were taken using a conical ichthyoplankton net with $500 \mu \mathrm{m}$ mesh and equipped with a flowmeter to estimate the volume filtered. The net was positioned approximately $2 \mathrm{~m}$ from one of the banks, preferably in areas with higher water velocity, and it was kept submerged for approximately 10 minutes at each sampling point. The collected samples were fixed in $4 \%$ formaldehyde. The screening and subsequent identification of ichthyoplankton were performed on Bogorov trays under a Carl Zeiss ® Stemi DV4 stereoscopic microscope. The egg and larvae densities were calculated for each sampling point and standardized in relation to number of individuals collected per $10 \mathrm{~m}^{3}$ of filtered water. The larvae were identified to the lowest taxonomic category possible according to Nakatani et al. (2001). Larvae were classified as unidentified when identification was not possible due to their initial stage of development or damaged structures.

Differences in ichthyoplankton density between the river sites were tested using the Kruskal-Wallis test. The eggs and larvae were classified by developmental stage according to the terminology described by Nakatani et al. (2001).

\section{Results}

An analysis of the conservation status of the areas surrounding rivers based on the percentage of remaining vegetation revealed intense anthropogenic activity in all tributaries and stretches of the Grande River. Except for the Cervo River, all rivers had less than half of the original vegetation (Table 3).

Table 3. Percentage of remaining natural vegetation established on both margins, at a distance of $1000 \mathrm{~m}$ to each side, along the entire river bed stretches of tributaries and the main river of the upper Grande River, Minas Gerais, Brazil

\begin{tabular}{c|l|c|c|c}
\hline & \multicolumn{1}{|c|}{ Stretch } & $\begin{array}{c}\text { Remnant vegetation } \\
\left.\mathbf{( k m}^{2}\right)\end{array}$ & Others $\left.\mathbf{( k m}^{2}\right)$ & $\begin{array}{c}\text { Percentage of } \\
\text { vegetation }\end{array}$ \\
\hline \multirow{5}{*}{ Tributaries } & 971,295 & 1265,079 & 43,4 \\
& Aiuruoca & 524,957 & 707,876 & 42,6 \\
& Capivari & 849,776 & 1879,465 & 31,1 \\
& Mortes & 528,206 & 442,514 & 54,4 \\
\hline \multirow{3}{*}{ Grande River } & Cervo & 122,975 & 241,888 & 33,7 \\
& Furnas-Funil & 167,242 & 347,399 & 32,5 \\
& Funil-Itutinga & 1103,117 & 1850,387 & 37,3 \\
\hline
\end{tabular}


Floodplain lakes were present and well distributed in all of the tributaries and stretches of the Grande River (Fig. 2). A total of 492 floodplain lakes were found. The Mortes and Aiuruoca Rivers had the most lakes among the tributaries, and the Grande River upstream of the Camargos reservoir had the most lakes among the stretches of main river course (Table 4). However, when considering the number of lakes per $\mathrm{km}$ of river, the stretch of the Grande River between Furnas and Funil had the highest value, followed by the Aiuruoca and Mortes tributaries. The Furnas-Funil stretch had also the highest total area of lakes compared with the other studied stretches, even though it had fewer lakes (Table 4).

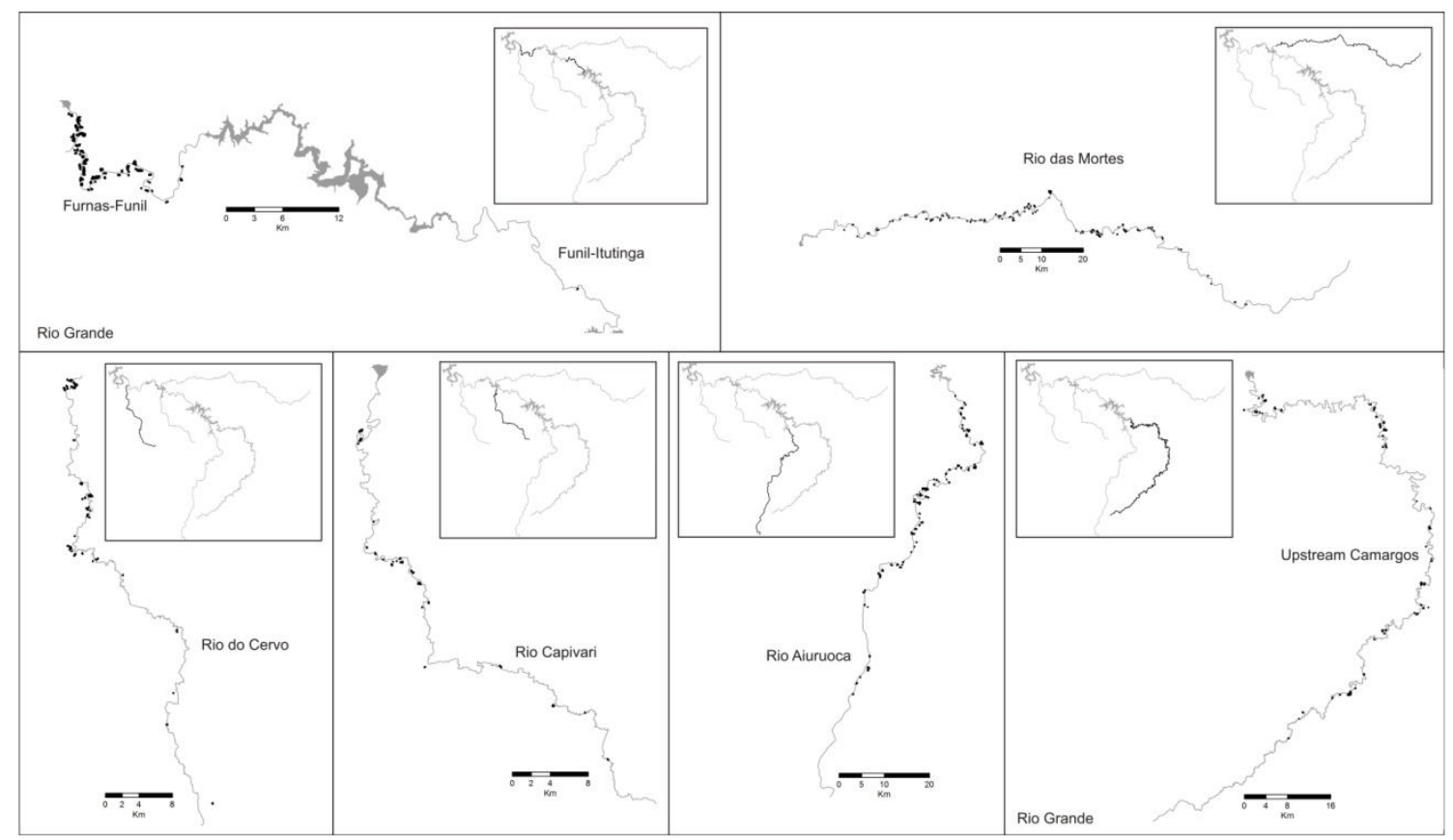

Figure 2. Resulting map of Landsat image object oriented classification in october 14, 2008, showing floodplain lakes in tributaries (Aiuruoca River, Capivari River, Mortes River and Cervo River) and stretch of Grande River (between Furnas-Funil, between Funil-Itutinga and upstream of the Camargos Reservoir), in the upper Grande River basin, Minas Gerais, Brazil

Table 4. Total number (n), total area $\left(\mathrm{km}^{2}\right)$ number per kilometer $(\mathrm{n} / \mathrm{km})$ of floodplain lakes along entire river stretch of tributaries and main river sampled during this study, in the upper Grande River basin, Minas Gerais, Brazil

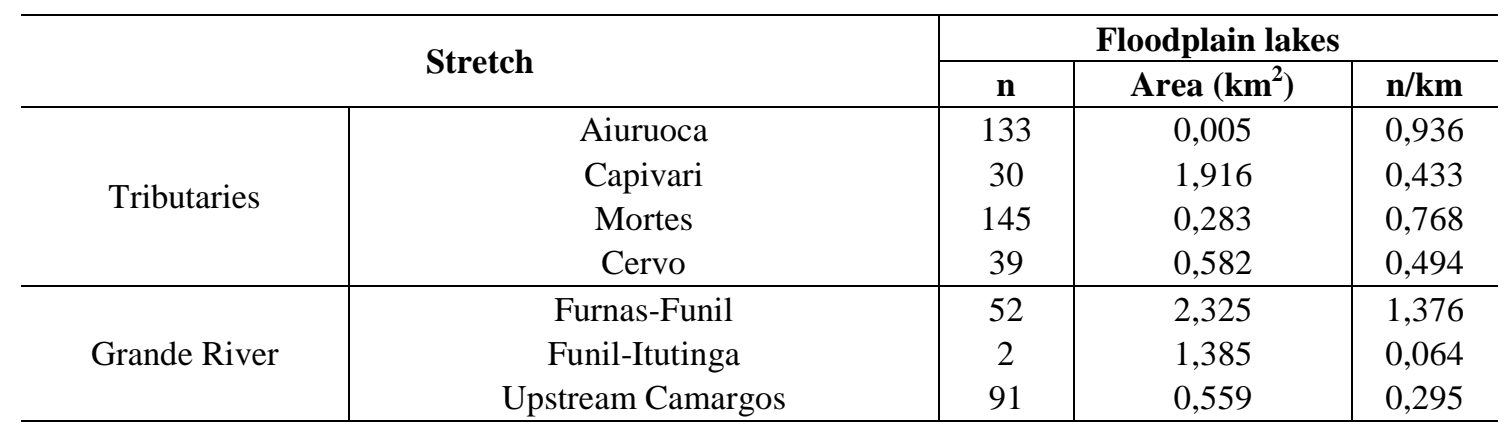


An amount of 7,111 eggs were collected during the study. Most of these eggs were collected from the Grande River between the Funil and Furnas $(28.4 \%)$ and from the Mortes River (24.5\%). Less significant collections included the Capivari (16.6\%), the Aiuruoca $(14.5 \%)$, the Grande River upstream of Camargos $(11.28 \%)$, the Grande River between the Funil and Itutinga (4.4\%), and the Cervo River (0.3\%). Eggs were not collected from the sampling points immediately downstream of the Funil and Itutinga dams.

Much fewer larvae were collected, totaling 230 by the end of the study. The most larvae were collected from the Mortes River (77\%), followed by the Capivari $(7.4 \%)$, Cervo $(1.3 \%)$, and the Aiuruoca $(0.4 \%)$. The remaining larvae $(13.9 \%)$ were collected from stretches of the Grande River: $12.6 \%$ between the Furnas and Funil and only 0.9 $\%$ and $0.4 \%$ from the stretches upstream of the Camargos reservoir and between Funil and Itutinga, respectively. No larvae were collected from the sampling points immediately downstream of the Funil and Itutinga dams during the study period. Among the larvae collected, it was possible to identify seven taxonomic groups (Table 5). The Heptapteridae and Pimelodidae families represented the Siluriformes order, while the Anostomidae and Characidae families represented the Characiformes order. There was only one sample recorded from the Gymnotiformes order; however, identification at a lower taxonomic category was not possible.

Table 5. Number and frequency of occurrence of larvae collected at each sampling site according to taxonomic group (RGI = immediately downstream of the Funil Dam; RGII = immediately upstream of the Funil Reservoir; RGIII = immediately downstream of the Itutinga Dam; RGIV = immediately upstream of the Camargos Reservoir; NI = nonidentified larvae). *Larvae identified by order. ${ }^{*} N I=$ Not Identified

\begin{tabular}{|c|c|c|c|c|c|c|c|c|c|}
\hline \multirow{2}{*}{ Taxa } & \multirow{2}{*}{$\mathbf{N}$} & \multirow{2}{*}{ FO } & \multicolumn{4}{|c|}{ Tributaries } & \multicolumn{3}{|c|}{ Grande River } \\
\hline & & & Aiuruoca & Capivari & Mortes & Cervo & RGI & RGIII & RGV \\
\hline Characiformes* & 8 & 3,48 & $\downarrow$ & & $\downarrow$ & $\bullet$ & 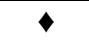 & & \\
\hline Anostomidae & 25 & 10,87 & & & $\bullet$ & & $\bullet$ & $\bullet$ & \\
\hline Characidae & 8 & 3,48 & & $\bullet$ & $\bullet$ & $\bullet$ & $\bullet$ & & \\
\hline Gymnotiformes* & 1 & 0,43 & & $\bullet$ & & & & & \\
\hline Siluriformes* & 108 & 46,96 & & $\bullet$ & $\bullet$ & & $\bullet$ & & $\bullet$ \\
\hline Heptapteridae & 8 & 3,48 & & & $\bullet$ & & & & \\
\hline Pimelodidae & 4 & 1,74 & & & $\bullet$ & & $\bullet$ & & \\
\hline NI & 68 & 29,56 & & $\bullet$ & $\bullet$ & $\bullet$ & $\bullet$ & & \\
\hline
\end{tabular}

A comparison of the total densities of eggs and larvae collected revealed the presence of spawning sites in tributaries of the Grande River, especially the Mortes River. Only one stretch between the Furnas and Funil in the Grande River had a significant collection of eggs and larvae (Fig. 3). 


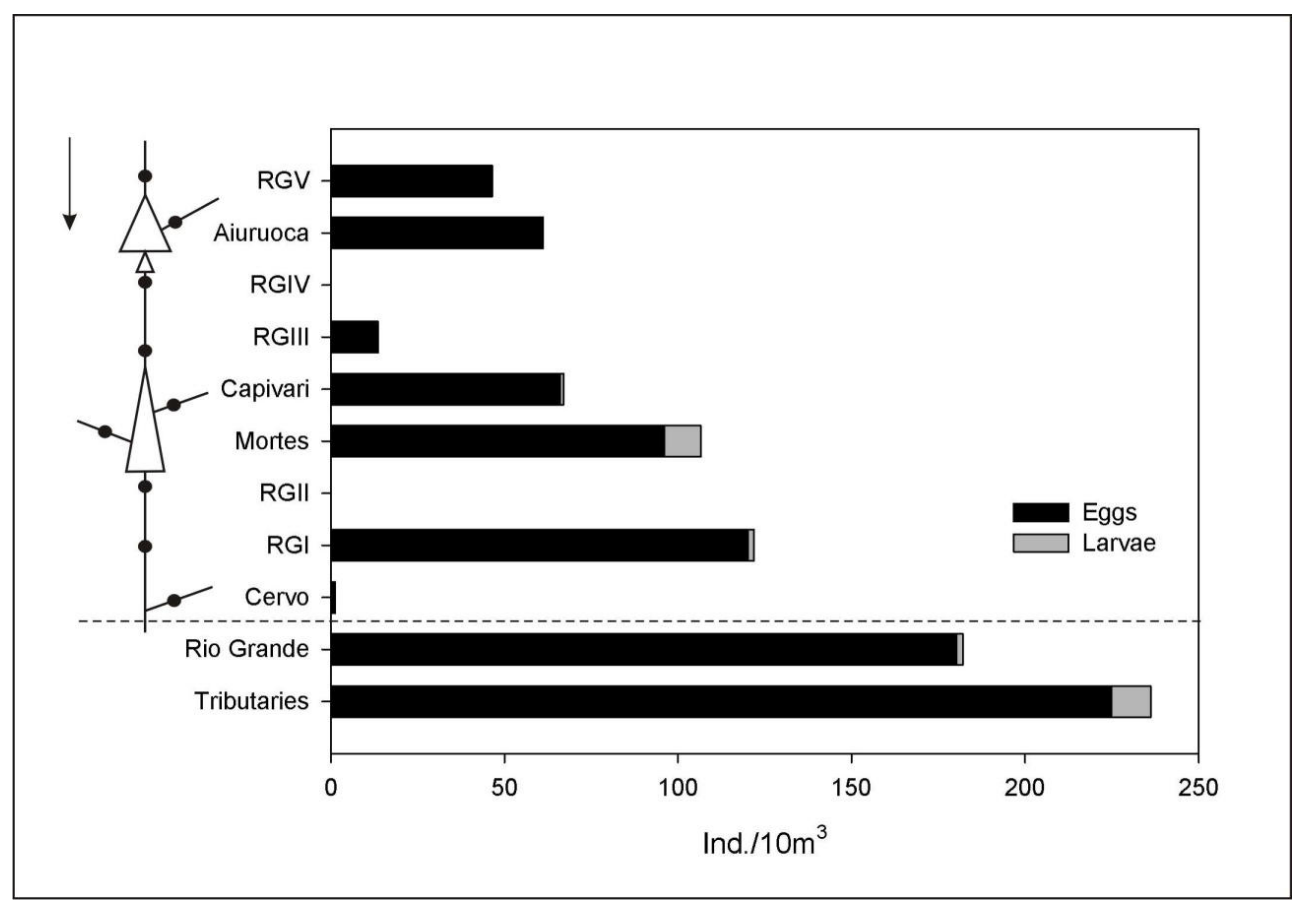

Figure 3. Total density of fish eggs and larvae at each sampling site and the sum of density in Grande River and in tributaries, from November 2008 to March 2009, in the upper Grande River basin, MG, Brazil. The illustration represents the sites where the ichthyoplankton was sampled. (Triangle $=$ reservoir, Black dot $=$ sampling site, Arrow $=$ flow direction, $R G I=$ between Furnas and Funil, RGII=immediately downstream of the Funil Dam, RGIII=between Funil and

Itutinga, RGIV=immediately downstream of the Ituting a Dam and $R G V=$ upstream of the Camargos Reservoir)

There was a significant difference in the mean density values of the eggs collected between the sampling sites (Fig. 4a). The studied tributaries, except for the Cervo River, had values very similar to each other, revealing important similarities in spawning areas. Higher variations were found between stretches of the Grande River, and the Furnas-Funil stretch had the highest mean value. The highest mean density of larvae was obtained in the Mortes River, followed by the Furnas-Funil stretch of the Grande River (Fig. 4b). 


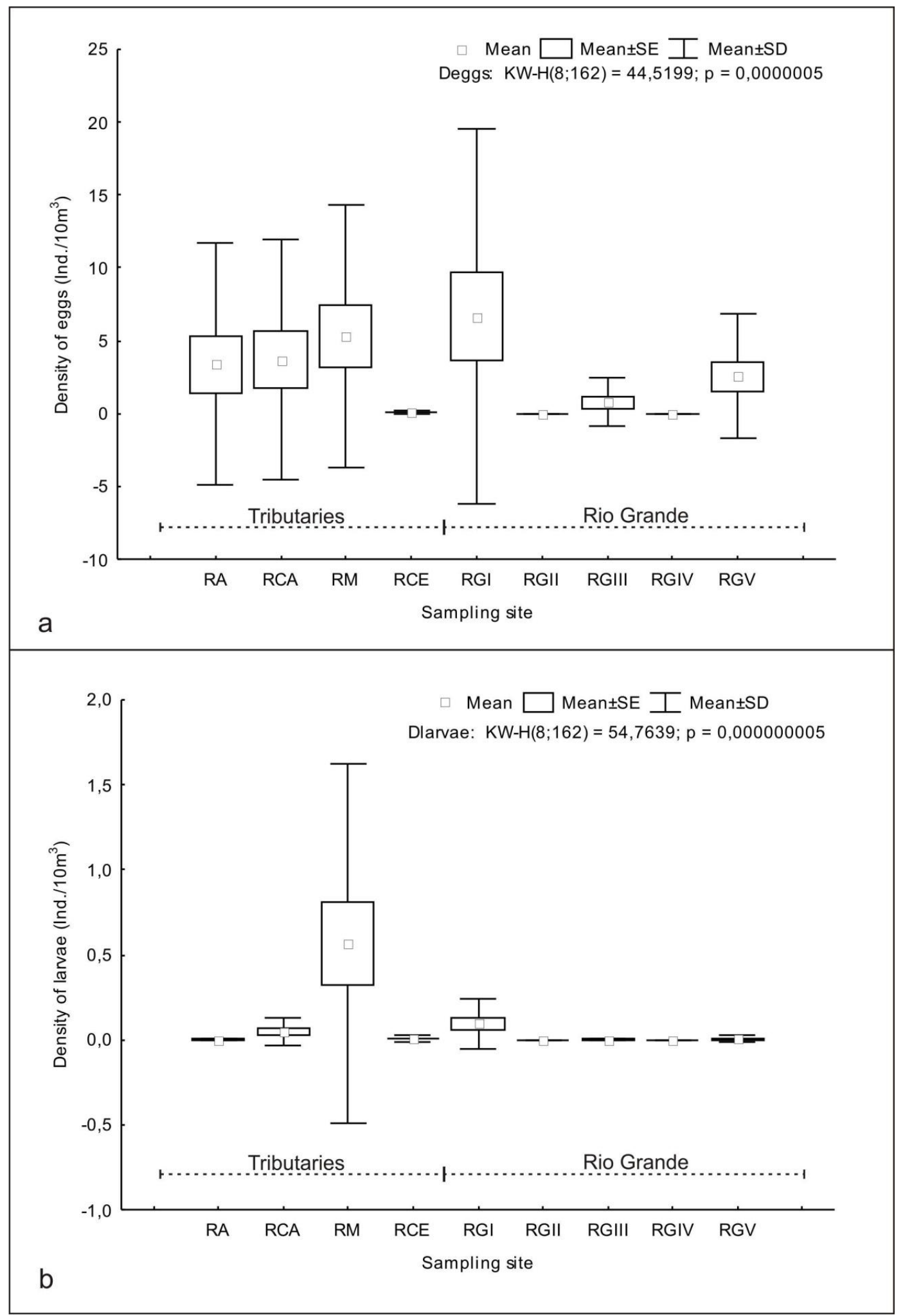

Figure 4. $\boldsymbol{a}-\boldsymbol{b}$. Box plot of the number of eggs (a) and larvae (b) at each sampling site, from November 2008 to March 2009, in the upper Grande River basin, Minas Gerais, Brazil. (RA = Aiuruoca River, $R C A=$ Capivari River, $R M$, Mortes River, $R C E=$ Cervo River, $R G I=$ between Furnas and Funil, RGII=immediately downstream of the Funil Dam, RGIII=between Funil and Itutinga, $R G I V=$ immediately downstream of the Ituting a Dam and $R G V=$ upstream of the Camargos Reservoir) 
Among the eggs collected, most were in the initial stage of development (first cleavage), except for those from the Mortes River stretch. Among the larvae collected, there was predominance of less advanced stages (newly hatched and yolk-sac larvae) in all of the sampled environments. The more advanced stages of both the eggs and larvae were less represented. The last stage of larval development (postflexion) was only present among the larvae collected from the Grande River, but in small quantity. A small difference among the different embryonic stages occurred at the Mortes River, where we found all egg developmental stages in addition to more larvae (Fig. 5).

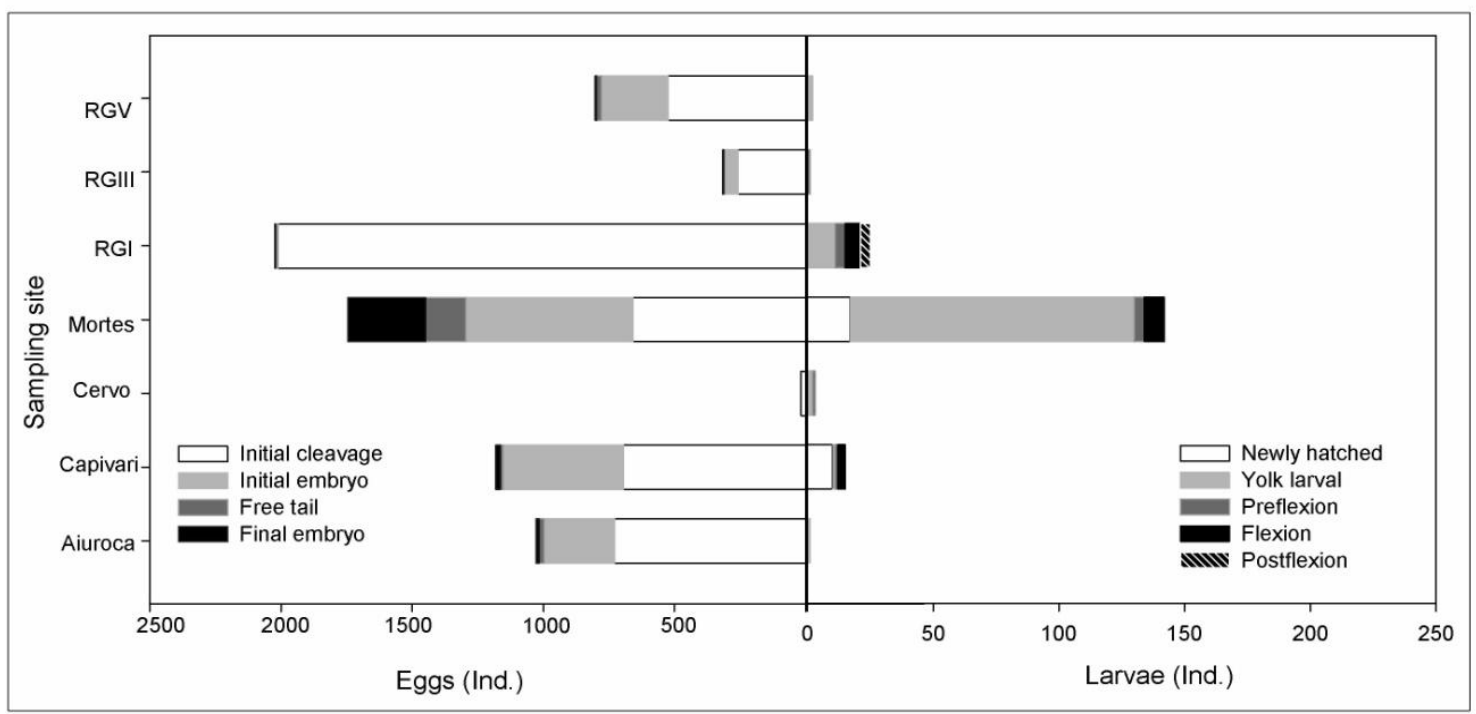

Figure 5. Spatial distribution of eggs and larvae number, and yours respective embryonic stage and post-embryonic, from November 2008 and March 2009, upper Grande River basin, Minas Gerais, Brazil. (RGI = between Furnas and Funil, RGIII = between Funil and Itutinga, and $R G V=$ upstream of the Camargos Reservoir)

From these results, it was possible to schematically represent the current situation of the upper Grande River basin in terms of the remaining vegetation surrounding the lotic stretches, the presence of nurseries (floodplain lakes), and spawning sites (egg and larvae drift) (Fig. 6). 


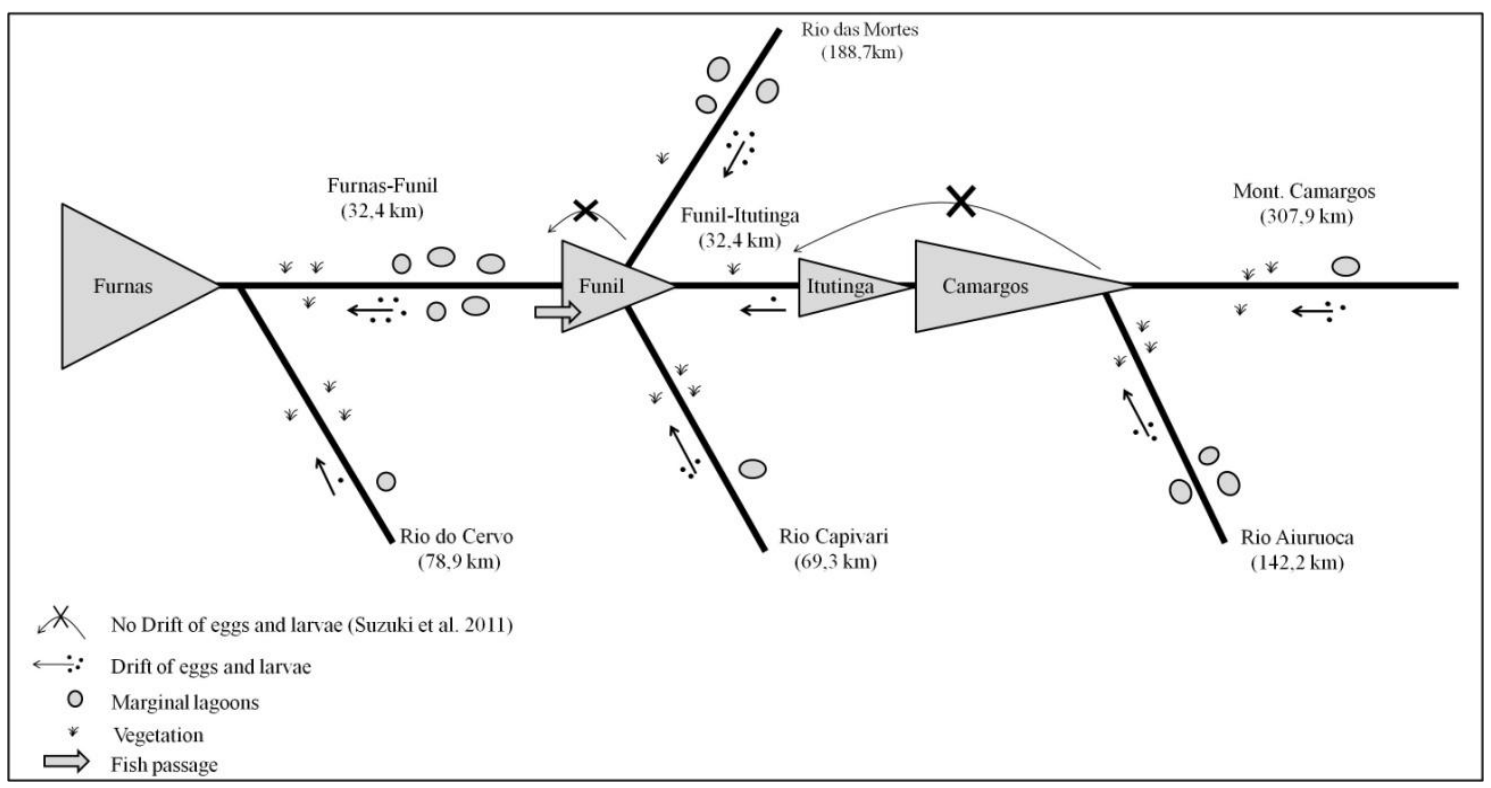

Figure 6. Schematic representation of current scenario in the upper Grande River basin with regard to remnant vegetation surroundings the rivers, from November 2008 and March 2009. The numbers illustrations (vegetation, floodplain lakes and ichthyoplankton) are represented in accordance with the scores attributed in each environment $(1$ point $=1$ illustration, 2 points $=$ 3 illustrations and 3 points $=5$ illustrations). The numbers in parentheses refers to the stretch

lotic extension

\section{Discussion}

Anthropogenic impacts on aquatic systems have increased in recent years, altering the hydrological cycle and deteriorating water quality (Tundisi and Matsumura-Tundisi, 2008). In addition to river impoundments, land use changes constitute one of the most evident impacts. The removal of vegetation that surrounds rivers not only alters drainage patterns but also increases sedimentation (Maitland, 1995), causing negative effects to fish assemblages (Jones, 1999). Because it directly reflects the state of environment conservation, assessing the integrity of the vegetation through mapping and quantifying the vegetation surrounding the rivers is essential for developing effective management plans for the conservation, protection, and restoration of aquatic systems (Tundisi and Matsumura-Tundisi, 2008). The results show that areas adjacent to lotic stretches of the upper Grande River basin, except for the Cervo River, have less than half of their original vegetation, with the vegetation possibly being removed for livestock practices (Scolforo et al., 2008). These activities are also evident in many areas surrounding the floodplain lakes of the upper Grande River basin, whose area should be protected because it was recognized as a permanent preservation area (Law 4771/65, September $15^{\text {th }} 1965$ ).

Floodplains are used as sites for feeding, reproduction, and initial development by many fish species (Junk et al., 1989; Lowe-McConnell, 1999). These environments generally have favorable conditions for larval development due to their higher temperatures and the presence of shelter and food (Humphries et al., 1999; Agostinho et al., 2003), and are important for both migratory and sedentary species (Ziober et al., 2007; Daga et al., 2009). The results of the present study reveal a large number of 
floodplain lakes along most of the studied river stretches, including all of the tributaries. However, it should be noted that the number of floodplain lakes can be overestimated by including seasonal lakes not connected to the river.

Tributaries often act as important spawning sites, as demonstrated by several studies on ichthyoplankton (Nakatani et al., 1997a; 1997b; Baumgartner et al., 2004; HermesSilva et al., 2009; Pinto et al., 2009). Due to their high density of eggs and larvae, the Mortes and Aiuruoca tributaries stood out as essential for fish recruitment in the basin. The presence of these tributaries is even more important when located between impoundments on the Grande River, where they may act as an alternative route for reproduction (Antonio et al., 2007; Pinto et al., 2009).

Despite the importance of tributaries for fish reproduction, the remaining lotic stretches of the Grande River were also important as spawning areas, especially the region between the Furnas and Funil. Reproduction in this region is essential because it is unlikely that ichthyoplankton have passage via the Funil reservoir to the floodplain lakes located there.

In contrast, a smaller number of egg and larvae were collected from the FunilItutinga stretch of the Grande River, reflecting the impact of large impoundments on fish reproduction and recruitment. Transparency and flow regulation by the Itutinga and Camargos reservoirs must be interfering with fish reproduction along this stretch (Suzuki et al., 2011). Increased transparency favors predation by visual predators, reducing the chances of offspring survival (Antonio et al., 2007). Flow regulation can affect fish recruitment in two ways: removing the appropriate conditions for reproduction and/or the conditions necessary for larval development (Humphries and Lake, 2000). Shields et al. (2000) emphasized the negative influence of lateral water movement dynamics, which reduce the formation of floodplains and explain the fewer floodplain lakes in this region.

The Funil hydroelectric dam is the only dam in the region that has a fish passage mechanism. This dam was initially thought to have spawning areas upstream and downstream, while the developmental sites were thought to be located downstream (Pompeu et al., 2011). The results of this study add the presence of initial developmental sites (floodplain lakes) in the lotic stretches upstream of the reservoir, primarily in the tributaries (Mortes and Capivari). Although the presence of the fish lift is important for maintaining connectivity between habitats, the functioning of this fish passage should be studied and carefully monitored because there is no descending ichthyoplankton migration downstream (Suzuki et al., 2011). The absence of this migration makes the Funil fish lift one way, which could compromise fish species recruitment downstream of the dam (Suzuki et al., 2011) and consequently undermine its value in conserving the basin's fish species (Pompeu et al., 2011). Its function should be primarily aimed at maintaining genetic flow between populations, where in principle, the populations upstream and downstream would be self-sustaining due to the occurrence of spawning and nurseries areas. It should be noted that this situation could change with the eventual construction of new hydroelectric dams upstream or downstream from this dam, especially in the Capivari and Mortes tributaries.

The more eggs observed compared with larvae, especially at the initial stage of development (first cleavage), may be related to the high fragmentation of the remaining lotic stretches in the region. Larvae were mainly collected from the Mortes River, a tributary long enough that the spawning sites are located sufficiently distant to allow the collection of forms at this initial stage of development. 
Among the taxonomic groups identified in this study, only the Gymnotiformes do own migratory species. In the Grande River basin, belonging to the upper Paraná River basin, most of the migratory species are known to be among the Characiformes and Siluriformes orders, specifically in the Characidae, Anostomidae, and Pimelodidae families (Agostinho et al., 2003), which were groups identified among the larvae collected in this study. It is noteworthy that migratory species exhibit non-adhesive eggs, while most sedentary species have some degree of egg adhesiveness (Rizzo et al., 2002). Migratory species among these taxa cover more than $100 \mathrm{~km}$ between different habitats to complete their life cycle (Agostinho et al., 2003), which is why these species are most affected by dam construction.

Given the presence of numerous breeding grounds and abundant floodplain lakes throughout most of the studied rivers, the creation of protected areas can be considered important management strategies for ichthyofauna conservation. This is necessary because new hydroelectric projects are planned for all of the remaining lotic stretches included in this study, with the exception of the Grande River upstream of the Camargos, which is already protected by state law (Law 15.082, April 27 ${ }^{\text {th }}$ 2004). The creation of these areas must be based on the concept of water corridors and knowledge of the life cycles of key species (Agostinho et al., 2005), considering all of the habitats required during their life cycle (King, 2004).

Although it is necessary to consider other parameters, such as richness (Pompeu et al., 2009) and the presence of umbrella species (Agostinho et al., 2005), the results obtained in this study (percentage of surrounding vegetation, number of floodplain lakes, egg and larvae contribution) are essential for aiding the development and implementation of future environmental action programs aimed at conservation, preservation, and recovery (Pompeu et al., 2009).

Acknowledgements. We thank Andréa Bialetzki for providing the internship opportunity, the Universidade Federal de Lavras for logistical help, FURNAS for funding this study. We also thank Mírian Castro and Lucas Pires for help with field and laboratory work.

\section{REFERENCES}

[1] Agostinho, A.A., Gomes, L.C., Suzuki, H.I., Júlio, H.F. Jr. (2003): Migratory fishes of the Upper Paraná River basin, Brazil. - In: Carolsfeld, J., Harvey, B., Ross, C., Baer, A. (eds). World Migratory fishes of South America: Biology,Social Importance and Conservation Status, The World Bank and International Development Research Centre, Victoria.

[2] Agostinho, A.A., Thomaz, S.M., Gomes, L.C. (2005): Conservation of the biodiversity of Brazil's Inland Waters. - Conservation Biology 19: 646-652.

[3] Agostinho, A.A., Gomes, L.C., Pelicice, F.M. (2007a): Ecologia e Manejo de Recursos Pesqueiros em Reservatórios do Brasil. - EDUEM, Maringá.

[4] Agostinho, A.A., Marques, E.E., Agostinho, C.S., Oliveira, R.J., Melo, J.R.B. (2007b): Fish ladder of Lajeado Dam: migrations on one-way routes? - Neotropical Ichthyology 5: 121-130.

[5] Aneel. Biblioteca. http://www.aneel.gov.br/biblioteca/index.cfm. Data of access: 17/12/2012.

[6] Antonio, R.R., Agostinho, A.A., Pelicice, F.M., Bailly, D., Okada, E.K., Dias, J.H.P. (2007): Blockage of migration routes by dam construction: can migratory fish find alternative routes? - Neotropical Ichthyology 5: 177-184. 
[7] Baumgartner, G., Nakatani, K., Gomes, L.C., Bialetzki, A., Sanches, P.V., Makrakis, M.C. (2004): Identification of spawning sites and natural nurseries of fishes in the upper Paraná River, Brazil. - Environmental Biology of Fishes 71: 115-125.

[8] Bittencourt, M.M., Cox-Fernandes, C. (1990): Peixes migradores sustentam pesca comercial. - Ciência Hoje 11: 20-24.

[9] Cemig, Cetec (2000): Guia ilustrado de peixes da bacia do rio Grande. - Cemig/Cetec, Belo Horizonte.

[10] Daga, V.S., Gogola, T.M., Sanches, P.V., Baumgartner, G., Baumgartner, D., Piana, P.A., Gubiani, E.A., Delariva, R.L. (2009): Fish larvae assemblages in two floodplain lakes with different degrees of connection to the Paraná River, Brazil. - Neotropical Ichthyology 7: 429-438.

[11] Godinho, A.L. (1993): E os peixes de Minas em 2010? - Ciência Hoje 16: 44-49.

[12] Godinho, H.P., Godinho, A.L. (1994): Ecology and conservation of fish in southeastern Brazilian river basins submitted to hydroelectric impoundments. - Acta Limnologica Brasiliensia 5: 187-197.

[13] Godinho, A.L., Kynard, B. (2009): Migratory fishes of Brazil: life history and fish passage needs. - Rivers Research and Applications 25: 702-712.

[14] Goulding, M. (1979): Ecologia da pesca do rio Madeira. - CNPq/INPA, Manaus.

[15] Hermes-Silva, S., Reynalte-Tataje, D., Zaniboni-Filho, E. (2009): Spatial and Temporal Distribution of Ichthyoplankton in the Upper Uruguay River, Brazil. - Brazilian Archives of Biology and Technology 52: 933-944.

[16] Humphries, P., King, A.J., Koehn, J.D. (1999): Fish, flows and flood plains: links between freshwater fishes and their environment in the Murray-Darling River system, Australia. - Environmental Biology of Fishes 56: 129-151.

[17] Humphries, P., Lake, P.S. (2000): Fish larvae and management of regulated rivers. Regulated Rivers: Research \& Management 16: 421-432.

[18] Jones, E.B.D., Helfman, G.S., Harper, J.O., Bolstad, P.V. (1999): Effects of Riparian Forest Removal on Fish Assemblages in Southern Appalachian Streams. - Conservation Biology 13: 1454-1465.

[19] Junk, W.J., Bayley, P.B., Sparks, R.E. (1989): The flood pulse concept in river in floodplain systems. - In: Dodge, D.P. (ed) Proceedings of the International Large River Symposium, Canadian Special Publication of Fisheries and Aquatic Sciences, Ottawa.

[20] King, A.J. (2004): Ontogenetic patterns of habitat use by fishes within the main channel of an Australian floodplain River. - Journal of Fish Biology 65: 1582-1603.

[21] Lowe-Mcconnell, R.H. (1999): Estudos ecológicos de comunidades de peixes tropicais. EDUSP, São Paulo.

[22] Maitland, P.S. (1995): The conservation of freshwater fish: Past and present experience. Biological conservation 7: 259-270.

[23] Meaille, R., Wald, L. (1990): A geographical information system for some Mediterranean benthic communities. - International Journal of Geographical Information Systems 4: 7986.

[24] Nakatani, K., Baumgartner, G., Bialetzki, A., Sanches, P.V. (1997a): Ovos e larvas de peixes do reservatório de Segredo. - In: Agostinho, A.A., Gomes, L.C. (eds) Reservatório de Segredo: bases ecológicas para o manejo, EDUEM, Maringá.

[25] Nakatani, K., Baumgartner, G., Cavicchioli, M. (1997b): Ecologia de ovos e larvas de peixes. - In: Vazzoler, A.E.A.M., Agostinho, A.A., Hahn, N.S. (eds) A planície de inundação do alto rio Paraná: aspectos físicos, biológicos e socioeconômicos: EDUEM, Maringá.

[26] Nakatani, K., Agostinho, A.A., Baumgartner, G., Bialetzki, A., Sanches, P.V., Makrakis, M.C., Pavanelli, C.S. (2001): Ovos e larvas de peixes de água doce: desenvolvimento e manual de identificação - EDUEM, Maringá. 
[27] Northcote, T.G. (1978): Migratory strategies in production in freshwater fishes. - In: Gerking, S.D. (ed) Ecology of freshwater fish production, Blakwell Scientific Publications, Oxford.

[28] Pelicice, F.M., Agostinho, A.A. (2008): Fish-Passage Facilities as Ecological Traps in Large Neotropical Rivers. - Conservation Biology 22: 180-188.

[29] Petrere, M. Jr. (1985): Migraciones de peces de agua dulce en América Latina: algunos comentarios. - COPESCAL Documento Ocasional, São Luis.

[30] Pinto, M.D.S., Melo, J.R.B., Freitas, I.S., Marques, E.E. (2009): Distribuição longitudinal da abundância de ovos e larvas de peixes no reservatório da UHE Peixe Angical. - In: Agostinho, C.S., Pelicice, F.M., Marques, E.E. (eds) Reservatório de Peixe Angical: bases ecológicas para o manejo da ictiofauna, Rima Editora, São Carlos.

[31] Pompeu, P.S., Agostinho, A.A., Pelicice, F.M. (2011): Existing and future challenges: The concept of successful fish passage in South America. - River Research and Applications. 28: 404-412.

[32] Pompeu, P.S., Reis, L.S., Gandini, C.V., Souza, R.C.R., Favero, J.M. (2009): The ichthyofauna of upper rio Capivari: defining conservation strategies based on the composition and distribution of fish species. - Neotropical Ichthyology 27: 659-666.

[33] Rizzo, E., Sato, Y., Barreto, B.P., Godinho, H.P. (2002): Adhesiveness and surface patterns of eggs in neotropical freshwater teleosts. - Journal of Fish Biology 61: 615-632.

[34] Sakamoto, T. (2007): Detecting temporal changes in the extent of annual flooding within the Cambodia and the Vietnamese Mekong Delta from MODIS time-series imagery. Remote Sensing of Environment 109: 295-313.

[35] Scolforo, J.R.S., Carvalho, L.M.T., Oliveira, A.D. (2008): Zoneamento ecológicoeconômico do Estado de Minas Gerais: componentes geofísico e biótico. - UFLA, Lavras.

[36] Shields, F.D. Jr., Simon, A., Steffen, L.J. (2000): Reservoir effects on downstream river channel migration. - Environmental Conservation 27: 54-66.

[37] Suzuki, F.M., Pires, L.V., Pompeu, P.S. (2011): Passage of fish larvae and eggs through the Funil, Itutinga and Camargos Reservoirs on the upper Rio Grande (Minas Gerais, Brazil). - Neotropical Ichthyology 9: 617-622.

[38] Tundisi, J.G., Matsumura-Tundisi, T. (2008): Limnologia. - Oficina de Textos, São Paulo.

[39] Weng, Q. (2002): Land use change analysis in the Zhujiang Delta of China using satellite remote sensing, GIS and stochastic modelling. - Journal of Environmental Management 64: 273-284.

[40] Ziober, S.R., Bialetzki, A., Gomes, L.C., Kipper, D. (2007): The importance of a floodplain lakes as a fish nursery in the upper Paraná River floodplain. - Acta Limnologica Brasiliensia 19: 369-381. 